\title{
Innovative Practices In Teacher Education
}

\author{
Bharti Varshney (Corresponding Author) \\ Assistant Professor, Department of Education, A.M.U. Centre, Murshidabad, West Bengal, \\ Contact No. 07407446388, E mail- varshneybharti@yahoo.co.in \\ Neelima Joshi \\ Research Scholar, Department of Education, A.M.U., Aligarh (UP)
}

\begin{abstract}
ABSRACT
Teacher education system is an important vehicle to improve the quality of school education. The revitalization and strengthening of the teacher education system is a powerful means for the upliftment of educational standards in the country. There are many issues that need urgent attention for improving the quality of teacher education programme. One of them is the need of innovations in teacher education programme. Innovativeness means the ability to think beyond the boundaries and create something which is different from that which already exists. Without innovations, no progress is possible. Teachers have to be innovative and their grooming has to start from their training institutions. Innovations in teacher education include IT literacy, interactive teleconferencing etc. NPE (1986) stated "The existing system of teacher education needs to be overhauled or revamped." Unfortunately, the secondary teacher education institutions in India are stated to be largely not innovative. There are some resisting factors in our education system which prevents the teacher education institution from being innovative such as lack of physical facilities and funds, lack of diffusion of innovations among teacher educators, rigid framework, lack of research orientation etc. In this paper the authors have tried to throw light on the need of innovations required in teacher education, the resisting factors and have also given suggestions to overcome those factors.
\end{abstract}

Keywords: Teacher Education, Innovation, resisting factors

Introduction

The quality of a nation depends upon the quality of its citizens. The quality of the citizens depends upon the quality of education system and the quality of education depends upon the combined efforts planners, educationists and administration, however, the most significant factor is the quality of the teachers. It means excellent and efficient teachers can change the fate of the nation. A teacher helps a child in bringing out the hidden capabilities. He/she unfolds what is within, hidden and untapped. He/she makes explicit what is implicit in the students. So teachers' importance in teaching-learning process is very much. The Secondary Education Commission (1952-1953) report stated, "We are convinced that the most important factor in the contemplated educational reconstruction is the teacher, his personal qualities, his educational qualifications, his professional training and the place that he occupies in the community." It is very right that, "no people can rise above the level of its teachers."(NPE, 1986). The Teacher is the real and dynamic force of any institution. A UNESCO publication, The Changing Role of the Teacher, states: 'There was a time when the teacher's role was to pass down to the younger generation the knowledge, experiences and mythology of a slowly evolving society. The pace of change in contemporary society has made this role redundant. The modern teacher must be, among other things, a change-agent. It does not matter whether one is addressing the situation in a developing country or an industrialized nation, the problem remains the same. What are the new dimensions of his [or her] role, and how is the teacher to be trained to fulfill that role. In examining the changing role of the teacher we need to see the changes as being a response to, and an attempt to confront, the pressures of a society undergoing constant transition.' (Goble and Porter, 1977) In facing up to challenges and impacts of globalization, high technology, economic transformation, international competition and local development in the new century, teacher education institutions should have made numerous educational reforms (Cheng, 2005). In these reforms, teachers and their schools have had to face uncertainties and challenges arising from their internal and external environments. As a consequence, the role of teachers has become more complex. In addition to teaching in the classroom, teachers are required to take up new responsibilities in school management, curriculum planning and development, mentoring new teachers, staff development, school-based action learning projects, and working with parents, outside leaders and professionals (Boles \& Troven, 1996; Cheng, Chow \& Tsui, 2001; Fessler \& Ungaretti, 1994; Murphy, 1995). How teachers can be prepared to take up these new roles and perform teaching effectively to meet the challenges and expectations from education reforms is crucial to the reform and practice of teacher education and professional development (Cheng, Chow \& Mok, 2004). This begs 
the question: what kinds of innovation and change should be made in pre-service teacher education to ensure this preparation?

Innovation means the ability to think beyond the boundaries and create something which is different from that which already exists. Without innovations, no progress is possible. No innovation or change can be implemented without teachers' awareness, involvement and commitment. Teachers have to be innovative and their grooming has to start from their training institutions. For having innovative teacher education, we have to reconstruct our educational system. Reconstruction of educational system started in India from the beginning of independence and efforts to improve teacher education can be traced back to that period. The University Education Commission(1953),Education Commission(1964-1966),International Secondary Education Project Team(1954), The Committee on Plan Projects(1963), The Study Group of the Secondary Teachers in India(1964),Indian Association Teacher Educators(1973),National Policy of Education(1986) and National Council for Teacher Education(1998)have all recommended innovations in India in order to meet the present day requirements and to strengthen all aspects of teacher education system.

\section{Initiative steps of Innovation in Teacher Education System:}

NPE (1986) stated "The existing system of teacher education needs to be overhauled or revamped."

This has resulted in a number of initiatives being launched and they are-

- Establishment of NCTE by the government of India on August 17, 1995 as a statutory body responsible for the regulatory as well as professional aspects of teacher education.

- Programme of Mass Orientation of School teachers (PMOST) was launched as a centrally sponsored scheme in all the states and Union Territories during 1986-1990.

- Special Orientation Programme for Primary Teachers (SOPT) was taken up in 1993-94 to provide orientation to primary school teachers.

- In the light of recommendations of NPE 1986, Block and Cluster Resource Centers were established for professional growth of elementary school teachers and heads.

- Interactive teleconferencing has been successfully tried in Karnataka and Madhya Pradesh in in-service training course.

- Three National Curriculum frameworks on Teacher Education have been brought out by the National council of Teacher Education (1978, 1988, and 1998).

- $\quad$ To acquire ICT literacy, the NCTE has produced a CD-ROM entitled 'IT Literacy'.

- NCTE has developed self learning modules on 'Human Rights and National Values' with a view to familiarize entrant teachers with values enshrined in our constitution.

\section{Innovative Programs in Teacher Education}

- $\quad$ B.C Ed. (1989) by DAVV, Indore

- M.C.Ed. (1991) by DAVV, Indore

- Master of Educational Technology (Computer Applications) by SNDT, University, Mumbai

- $\quad$ M.Tech. (Educational Technology) by Kurekshetra University, Kurekshetra

- B.Sc. in Teaching Technology by Sikkim Manipal University

- $\quad$ HSTP Training Teachers, Eklavya, MP(1982)

- $\quad$ Activity Based Teacher Education Program, DAVV, Indore (1991)

- Personalized Teacher Education Program, Lucknow University, Lucknow (1996)

- Comprehensive Teacher Education Program, Gandhi Shikshan Bhavan College of Education, Mumbai University, Mumbai (2000)

- Four Year Integrated Program of Teacher Education, Kurekshetra University, Kurekshetra (1955)

- Four Year Integrated Program of Teacher Education, RIE, NCERT(1963)

- B.Ed. (Educational Technology), AEC Teacher Training College, Pachmadi, MP

- $\quad$ Early Faculty Induction Programme (EFIP) under QIP by AICTE ,New Delhi

- Induction Training Programme ( ITP) under QIP by AICTE, New Delhi

- University of Teacher Education, Chennai, Tamilnadu (2008)

- IGNOU Institute of Professional Competency Advancement of Teachers (IIPCAT, 2009), IGNOU, India

- Indian Institute of Teacher Education, Gujarat (Bill 4, 2010)

\section{FEATURES OF SOME OF THE INNOVATIVE PROGRAMS}

\section{Personalized Teacher Education (DAVV, 1991)}


Activity based Teacher Education Program (Zero Lecture Program) originated and institutionalized at the School of Education, DAVV, Indore (1991) was deployed at Lucknow (1996). Some of the features of this Program are:

$>$ Choice of Volunteers

$>$ Learner Centered

$>$ Personalized Classroom Setting

$>$ Participatory Approach

$>$ No lectures by Teacher Educators (ZLP)

$>$ Freedom for what to study, how to study, where to study, and when to study Peer Teaching-LearningEvaluation

$>$ Variety in the modes of presentation

$>$ Successive Discussions

$>$ Evaluation- Self, Peer, and Teacher Emergence of Humanistic, Friendly, Confident, Open, Resourceful, Dedicated, Creative, Constructive, Innovative and Wholistic Masters.

2. Wholistic Teacher Education (CASE, 2008) Problem solving in higher education through participatory approach $(D A V V, 1992)$

The Centre for Advanced Studies in Education (CASE), Vadodara has been strengthening Wholistic Teacher Education through seminars, research and publications. A Research Study has been conducted on rehabilitation of Street Children through Wholistic Approach. Some Research Studies are being conducted on Wholistic Science Education Program and Wholistic Development through Leisure Time Activities. The wholistic teacher education program is quite promising. Some of the features of the program are:

$>$ Subject Knowledge

$>$ Inter-disciplinary

$>$ Environmental Attitude

$>$ Health development

$>$ Emotional development

$>$ Spiritual development

$>$ Integrated development

\section{Problem solving in higher education through participatory approach (DAVV, 1992)}

The M.C.Ed. Class (1992), DAVV, Indore was very often given a problem to be solved through a computer program. Number of different programme would emerge from the entire class. Each program was presented by one of the programmers to the rest of the class and rated by all the students on different criteria, namely, compactness of source code, fetch and execute cycle size, response time, memory used, programming discipline level and programme intelligibility. Also, the students developed programme to calculate Kendell's Coefficient of Concordance through ' $\mathrm{C}$ '

language. They then computed Kendell's coefficient of concordance individual criterion wise and with respect to the comprehensive criteria. There is a significant cognitive development through cognitively mapping the algorithms and solution to a problem. This approach cuts across students of varied profiles, simultaneously. Participatory approach may be introduced in various disciplines to enhance learning in all domains. It facilitates creative production and independent thinking. Also, it provides scope to experience and appreciate the cognitive maps of others.

\section{Development of Creative Writing Ability Amongst Students Through Participatory Approach (CASE,} 2010)

$>$ Recitation of Model Poems by the Teacher in Class situation

$>$ Appreciation of the poem by the class and identification of the various components of creative composition

$>$ Composition of a variety of poems by the students individually, and in groups Recitation of the selfcomposed poems by the classmates and appreciation by rest of the class

$>$ Participatory approach of creative writing facilitates expression of the latent creative faculties in terms of original production. 


\section{IGNOU Institute of Professional Competency Advancement of Teachers (IIPCAT, 2009), IGNOU, India}

\section{Vision \& Mission}

The vision of IIPCAT encompasses improvement in the quality of education by continuously striving for competency advancement of teachers of different disciplines at all stages of education, that is, Pre-School, Primary, Upper Primary, Secondary, Senior Secondary, and tertiary stages of education. It shall endeavor to develop itself as an effective vehicle to transform the modality of curriculum transaction in educational institutions so as to improve the quality of education in particular and of human life in general. The mission of the IIPCAT shall include competency advancement of teachers of all levels and in all aspects of teachers' functions and responsibilities. To accomplish this mission, the IIPCAT shall use multiple strategies, such as, organization of in-service education, preparation of quality reference material, making arrangements for practical training. There is hope that as a result of the interventions of the IIPCAT, the teachers will relatively be more enlightened, professionally competent and socially responsive.

\section{The Indian Institution of Teacher Education, Gujarat (Bill, 2010)}

This is a Bill to establish the Institute of Teacher Education to promote teachers' development of integral personality, wide vision of nationalism and internationalism and to fulfill their role as exemplars, as friends, philosophers and guides, as scientists, psychologists, artists and technologists and above all as ideal communicators who can spread uplifting influence by the processes of awakening, inspiration, and enthusiasm, also to new trends of syntheses of the East and the West and agents of change from old to the new and to confer the status of a University thereon and for matters connected therewith or incidental there to.

\section{Integrated Teacher Education}

Integrated Teacher Education Programs have been found to have a mixed scenario. Some are alive, some have died, whereas, some are taking birth. The Integrated Teacher Education Programs offered by the Regional Institutes of Education since many years have self -recognition and accreditation. There is a need to conduct research on the integrated Teacher Education Programs offered by the various institutions. There is also a need to mentor and monitor the Innovative Teacher Education Programs in all the regions.

\section{Technology Integrated Teacher Education}

There is technological revolution in Teacher Education. There is a shift from Bachelor of Teaching to Bachelor of learning, that too, Bachelor of e-Learning. There is a shift from e-Learning 1.0 (Online learning) to e-Learning 2.0 (Twitters, Face-book) to e-Learning 3.0 (Semantic Web), that is, from content to community to Artificial Intelligence. There is a quick shift from web-1 to web-2 to web-3. We have initiated into Open Education, Open Course Ware, Open Source Software, Open Content and Open Research. There are proposals for e-Teacher Education. Smart Classrooms are emerging, wherein; we have e-learning and e-testing. Terms like Wi-Fi, iPad, e-Book, e-Reader, e-News Letter, Webinar are widely used. Digital Lesson Designs and e-Portfolios have become common features. There are compendiums of abstracts and Surveys of Educational Research in India on the World Wide Web. The NCTE is expediting Teacher Education on e-Technologies through an MOU with the Intel. There is wide scope for transformation of Teacher Education through Technology.

\section{Resisting Factors in Innovation:}

Although there are so many innovative practices existing in Teacher Education Programme in India, but still there are some resisting factors in our education system which prevents the teacher education institution from being innovative and they are-

1. Lack of Physical facilities and Funds - Majority of colleges suffer from lack of facilities in terms of space, equipment and personnel. Consequently, they have mot been able to adopt innovations. For want of these facilities, many creative ideas are shelved.

2. Lack of Diffusion of Innovations among teacher educators - Most of the teacher education institutions is poor and indifferent towards the professional growth of their teacher educators. Many of the teacher educators are ignorant of the new trends in their area of studies due to lack of diffusion of new ideas among them.

3. Lack of Service - Due to administrative difficulties, teacher educators are not able to try, adopt and maintain innovations in teacher education institution. For any new experimentation, facilities are not usually provided by the administrators.

4. Lack of Support - It is unfortunate that teacher educators have not been able to adopt innovations due to noncooperation of practicing schools. The schools are not always willing to extend their facilities to the 
teacher educators for trying out new ideas because they do not want any disturbances in their daily routine.

5. Rigid framework - It is found that the rigid system of syllabus framing and theory respectively are responsible for the continuance of the traditional practices in teacher education Programme. The present examination system under a rigid framework is a biog stumbling block in the process of innovation.

6. Lack of Expertise of the staff - Majority of secondary teacher education institutions are manned by teacher educators who have not been exposed to the functioning of institutions inside or outside the country Moreover, it is found that due to lack of expertise of the staff members, innovations have not been diffused in the training institution.

7. Lack of Research Orientation - A vast majority of teacher educators have not yet developed research mindedness. Whatever Programme and practices have been adopted in the training institutions, they have been adopted on commonsense basis not on research findings.

8. Interpersonal Relationship Crisis - Teacher educators feel that there is a lack of cooperation among members of the staff. There are professional rivalries among co workers and there is no initiative from teacher educators for creative works. It appears that lack of interpersonal relationship is yet another factor preventing the spread of innovation in the training institutions.

9. Decision making by external agencies - Teacher educators simply follow the decisions taken outside by the university and government authorities for the adoption of innovations in their teacher training institutions. Teacher educators lose initiative and desire to venture innovation even in the areas which fall within their purview such as methods of teaching, supervision and guidance to student teachers.

\section{Suggestions}

The above observations clearly indicate that teacher education programme at secondary level needs to be examined critically in terms of its innovativeness. Here are some suggestions which can be used to overcome these problems-

- Identification of the innovative research could be done if all the Departments of Education Countrywide contribute in this area. They may periodically produce the Research Abstracts of the Studies conducted in their respective Departments, which may be made available on the World Wide Web.

- Every Teacher Educator may be given Unique Identification Number. It will facilitate Manpower Planning in Teacher Education.

- There should be networking amongst all the Teacher Education Institutions to learn from the innovative practices of each other.

- Efforts should be made to realize wholistic Teacher Education by integrating various skills, such as, microteaching, info-savvy, techno-pedagogic, life skills in the various Teacher Education Programs. Along with cognitive development there should be adequate focus on emotional maturity, psycho-motor development, health and environment, and inter-disciplinary development.

- It is imperative to strengthen Vocational Teacher Education in almost all the domains of Vocational Education, such as, agriculture, horticulture, sericulture, servicing of the electric and electronic appliances. Innovative approaches need to be evolved.

- Physical facilities and funds should be adequately provided to the institutions by the government, local bodies and organizations.

- The internship model of practice teaching should be adopted. As some private universities such as Institute of Education and Research in Manglayatan University, Aligarh, G.E.A.R. (Gifted Education and Research) Innovative B.Ed. College, Bangalore, Prince Institute of Innovative Technology, Greater Noida etc. have already adopted. In the same way, government universities should include it in their teacher training programme.

- The conventional system of a few demonstration lessons given by a few teacher educators at the beginning of the practice teaching may be replaced by display of some video recorded good lessons in each subject delivered by expert teacher educators, teachers and teacher trainees.

- Relevant methods of instruction such as tutorial, discussion seminar, team teaching and interactive teaching learning should be adopted.

- More co-curricular activities such as physical education, social services, tree plantation, and formation of eco club should be organized.

- Modern technological gadgets like computer, video, mass media, OHP should be used at the time of instruction.

- Counseling and follow up programs should be initiated and made effective.

- In service and extension services should also be organized frequently. 
- Teaching staff should be given adequate representation in the management.

- The teacher educators should be made mobile so that they can see their professional world outside their institutions.

- The service and support from practicing schools, administrators, students- teachers, guardians and community should be encouraging.

- Teacher educators shall be given proper incentives for the professional growth.

- Publication and subscription to professional journals by the institutions should be encouraged.

- Research wings in the university departments and selected government colleges should be started.

- A healthy relation among teaching staff would evolve new procedures and move towards new goals.

- The management and administrators should be watchful in maintaining the health of the institutions so as to make them innovative and progressive.

\section{Conclusion}

To meet the challenges of the new millennium, teacher education in India needs a tremendous change. The teacher educators need intensive training in various aspects related to new innovations. The above stated problems are challenging and strategies to overcome these problems are the need of the hour. Therefore NCTE, SCERT/SIE and university department of education should take immediate action for making education system innovative. There is nothing to get disheartened. Indian Education is a state of flux. The national vision mission will definitely nurture innovations as evident through the emergence of National Curriculum for Teacher Education (NCTE, 2009) and Teacher Education: Reflections towards Policy Formulation (NCTE, 2009). There are proposals for Integrated Innovative Teacher Education Programs (Navrachna University, Vadodara, 2009 Carolex University, Ahmedabad, 2009). A Bill is through on The Indian Institute of Teacher Education, Gujarat (Bill 4, 2010) which envisages establishing a Centre of Excellence in Teacher Education for Research, Training \& Development, Extension Capacity Building to Exhilarate and Enthuse Educators and Institutions. There is Research for Wholistic Education. Even the general streams of Science and Arts have realized the importance of Teacher Education (Gandhi gram Rural University, Dindigul). Attempts are being made for enhancement of professional competencies of teachers through ICT mediated Constructivist Approach. India is committed to compatible education for all, which is being realized through the various dedicated programs, essentially innovative in nature.

\section{References:}

- $\quad$ Boles, K., \& Troven, V. (1996). Teacher leaders and power: Achieving school reform from the classroom. In G. Moller \& M. Katzenmeyer (Eds.), Every teacher as a leader, new directions for school leadership, No. 1. San Francisco: Jossey-Bass.

- Cheng, Y. C. (2005). A new paradigm for re-engineering education: Globalization, localization and individualization. Dordrecht, The Netherlands: Springer.

- Cheng, Y. C., Chow, K. W., \& Mok, M. M. C. (Eds.). (2004). Reform of teacher education in Asia-Pacific in the new millennium: Trends and challenges (pp. 1-238). Dordrecht, The Netherlands: Kluwer Academic Publishers.

- Das,B.C.(2011).What prevents Teacher Education Institutions from being Innovative,Edutracks, Vol.10 (6), p.15-18

- Dash,Sankarsan (2006).Quality improvement in teacher Education: An analysis of and future, Edutracks, vol.7 (9)

- D.R. Goel and Chhaya Goel(2010), Innovations in teacher education, Journal of Engineering, Science and Management Education, Vol. 1, 2010,pp.24-28

- Fessler, R., \& Ungaretti, A. (1994). Expanding opportunities for teacher leadership. In D. R. Walling (Ed.), Teachers as leaders: Perspectives on the professional development of teachers. Indiana, IN: Phi Delta Kappa Educational Foundation.

- Goble, Norman M. and James F. Porter. 1977. The Changing Role of the Teacher: International Perspectives. UNESCO Paris. p. 234.

- Kothari, R.G. (2009), Teacher Education programme at secondary level: some issues, University News, Vol.47 (25), June 22-28.

- Murphy, J. (1995). Changing role of the teacher. In M. J. O'Hair \& S. J. Odell (Eds.), Educating teachers for leadership and change, teacher education yearbook III. Thousand Oak, CA: Corwin Press.

- Mok, M. M. C., \& Cheng, Y. C. (2001). Teacher self-learning in a networked environment. In Y. C. Cheng, K. W. Chow, \& K. T. Tsui (Eds.), New teacher education for the future: International 
perspectives (pp. 109-144). Hong Kong \& the Netherlands: Hong Kong Institute of Education \& Kluwer Academic Publishers.

- Rout, S.K.(2008).Quality of teacher education Programme: a few problems and strategies,Edutracks, Vol.7(9)

- Vadhel, V.G.(2009)Teacher: A dynamic Innovator since Ages, University News, Vol. 47(35),Aug31Sep 06

- Yadav, S.K. (2006).Teacher of education in India: issues and concerns, University news, Vol. 44 (38), Sep18-24. 